\title{
Financial Literacy for Elementary School Students: Case Study of Bandung City, Indonesia
}

\author{
Delila Saskia Puspitarona, Ishak Abdulhak and Rusman \\ Indonesia University of Education \\ Bandung, Indonesia
}

\begin{abstract}
The objective of this research is thus to figures out the elementary school students' profile on financial literacy. The study takes a case study in Bandung, Indonesia, through a primary survey conducted from January to March 2019 in several elementary schools. The main findings of this study reveal the elementary school students' actual profile in financial issues in their daily life experiences. These results are significant for the policymaker, academics, and practitioners in the field of elementary education to designing financial education programs and curriculum.
\end{abstract}

Keywords: financial literacy, elementary school, financial profile, financial education.

\section{Introduction}

Global attention on the importance of financial literacy is increasing at any age levels (Blue \& Brimble, 2014; Aflatoun \& UNICEF, 2012; OECD, 2012). These include early childhood, pre-teens, adolescents, adults, or even the elderly who have to manage their retirement life. Some scholars define financial literacy as a skill that must be possessed by someone to adapt to a future life (e.g. Allan, 2011; Blue, 2016). Hence, these skills also referred to as part of 21st-century life skills (Cameron et al., 2014; Trilling \& Fadel, 2009). As an essential skill in the present and future era, financial literacy has become a global issue in which some developed countries have begun to develop various financial education programs. For example, public education programs related to financial services and products, training and consultancy in the field of business management, etc. (Blue \& O'Brein, 2016). Therefore, the development of financial literacy has been established to be part of the learning process in schools for these countries (Cameron et al., 2014).

Financial literacy programs have been put forward since 2008 at the G-20 countries meeting organised by the Organization for Economic Co-operation and Development (OECD). As a result, the International Networking on Financial Education (INFE), established in 2008 as a unit under the OECD. The 
organization has tasks in carrying out promotions, research, and facilitate international corporations on the issue of increasing financial literacy. From the INFE's survey in 2013, the OECD has succeeded in developing the Core Competencies Framework that must be possessed by school-age children related to financial literacy (OECD, 2013. The survey conducted in the OECD member categorized as developed countries. The following action from the investigation leads to the development of the core competency framework that students must master in the realm of financial education (Lusardi, 2015).

Some other regional forums also concerned with the importance of financial literacy for the early age children. For example, the Asia Pacific Economic Cooperation (APEC) supports to integrate financial literacy as essential life skills that must be possessed by every child. Furthermore, the World Economic Forum (WEF) in 2016 also issued an agreement on the six financial literacies that must be owned as provisions for life skills in the 21st century. The six literacy competencies are language literacy, numeracy literacy, scientific literacy, digital literacy, financial literacy, and cultural and citizenship literacy. In 2015, the OECD conducted an international student assessment, i.e. the Program for International Student Assessment (PISA). The survey presented a more detailed analysis framework, definition and description, which included some domains, namely scientific literacy, language literacy, mathematical literacy, and financial literacy (OECD, 2017).

Against to the global context, Indonesia, as a developing country and a member of the G-20, has been lacking behind in the field of financial literacy. The profile of the Indonesian public's awareness of financial management by the results of the Financial Services Authority (Otoritas Jasa Keuangan - OJK) national survey on financial literacy and inclusion shows in which only $29.7 \%$ of the population are well literate. According to OJK, most of Indonesian people have used financial products and services without adequate financial understanding. The survey also reveals that the level of student financial literacy shows even lower numbers, which is about $23.4 \%$ of the overall national level percentage. In addition, the survey show that the financial goals of Indonesian people are still dominated by short-term goals, predominantly to fulfil their daily life and to survive, in which from the $96.7 \%$ of the people who have financial goals, $69 \%$ of them have financial goals to fulfil their daily life, and only $12.6 \%$ who have prepared long-term goals, such as for their children's education, and $6.3 \%$ have financial goals for the retirement preparation (OJK, 2016).

Based on the data from the OJK survey, it becomes a mandatory prerequisite for the Indonesian people in facing 21st-century to mastering in financial literacy. Financial literacy competence is not just about knowing money but is a concept of the introduction of financial management and the ability to control financial expenditure by distinguishing between needs and wants (Cole et al., 2009). Financial understanding among elementary school students then becomes an urgent need to be studied as a foundation for the preparation of a more optimal financial education program in the country. The existence of financial education curriculum is hoped to improve financial literacy as a component to instil 
positive values in dealing with increasingly uncertain life situations (Aflaton \& UNICEF, 2012).

There are some other reasons why financial literacy for children are essential in addition to the above factor. Firstly, children need to be prepared to be individuals who are tough, wise, reasonable, have principles, and responsible for acting and making decisions for their interest (CUNA, 2005; Habschick et al., 2007). Secondly, the period of children and pre-teens is the foundation for adult individuals so that in this period the development of various life skills need to be equipped in dealing with multiple problems occur in their daily life (Triling \& Fadel, 2009). Thirdly, financial education is imperative to improve financial literacy that will be one of the knowledge and skills possessed by adolescents in dealing with real-life problems at a later age (Blue, 2016). Finally, from an educational standpoint, preparation and development of financial literacy should be carried out on an ongoing basis, so that if PISA assesses the 15-yearold students (end of junior high school and junior high school), the financial education should be implemented long before the children enter their junior high school.

Nevertheless, research and surveys conducted by the Financial Services Authority $(\mathrm{OJK})$ are undertaken only at the age of children 13 years and older, or the junior high school level and beyond (Senjiati et al., 2018). Besides, academic research on the topic of financial education or increasing financial literacy, particularly in developing countries, such as Indonesia, is rarely found. In addition to the lack of previous studies, other researchers assume that children financial activities are influences by socio-cultural conditions. For example, in Indonesia, children generally begin to carry out simple economic activities at an early age, for instance, using their allowances for shopping and buying snacks. These activities correspond to findings in other countries in which children are also receiving money as a gift, choosing a lifestyle for self-expression and social acceptance, etc. (Van-Campenhout, 2015; Sherraden, 2012; Robson, 2012; Cochran, 2010).

For the case of Indonesia, despite the national literacy movement has been launched on a national scale, elementary schools have not been touched to carry out financial literacy programs. In the preliminary survey conducted by the Ministry of Education and Culture (2015), it is found that the National Literacy Movement launched by the government is merely understood and targeted for school teachers in the aspect of language literacy, while the other 5 (five) literacy, namely numeracy literacy, scientific literacy, digital literacy, financial literacy, and cultural literacy and citizenship. However, the movement has never been socialised and even practised in elementary schools.

Since 2015 PISA has conducted an assessment of financial literacy. It defines financial literacy is relevant for the youth around 15 years old OECD (2019). But in other hand, OECD Australian Securities and Investments Commission (2012) has argued that is essential to provide financial education to children as early as 
possible, to foster the ability to consider finances, especially relating to personal matters such as the allowance they have (ASIC, 2012).

To explore the financial literacy in elementary school student, the question of this research are:

1. How is finance experience in elementary school student daily life?

2. How the elementary school student's opinions about money management?

3. How the elementary school student learn about money management?

\section{Research Purpose}

This research is conducted to fill this gap by providing an overview of the elementary school students' profile on financial literacy through assessment of their daily experiences of their interaction with financial matters.

\section{Literature Review}

The definition of financial literacy is a life skill that humans need to have in the 21st century (Lusardi, 2015; Blue, 2016). Financial literacy is a concept that is currently being heavily discussed, and is a competency that must be possessed by every student throughout the world in accordance with recommendations from the OECD's Center for Education Research and Innovation for students to face the 21st century that needs to develop a financial education in the formal curriculum education (OECD, 2005; Jorgensen \& Savla, 2010).

The general understanding of financial literacy is the knowledge and skills to process financial information, which includes financial concepts, motivation, and confidence to make effective financial decisions in various contexts (Cole, 2009; OCED, 2012; Holden et al., 2009). Financial literacy can be interpreted as financial intelligence, which is shown by a person's ability to manage their finances based on controlling their internal and external impulses to choose priorities between their wants and needs. This definition refers to the opinion of Xu \& Zia (2012) which states that financial literacy is a concept that extends from financial awareness, financial knowledge (knowledge of financial products/institutions), to understanding financial concepts (such as the ability to calculate payments, management and financial planning, etc.).

Financial literacy is more than just knowledge or ability, but rather the competence of one's actual behaviour in the financial aspect (Lee, 2010; Holden et al., 2009). Financial literacy involves the knowledge dimension and the application dimension (Huston, 2010). Financial literacy refers to an individual's capacity in financial knowledge and applies it to financial dilemmas faced at various stages of life. It also involves a critical reflection on the impact of individual financial decision making (Hidajat, 2015; Fernandes et al., 2014), how this affects others, considering what influences their financial decisions (i.e. socioeconomic status, education level, values, personal and cultural, life stages, social standing and professional associations, media and marketing, and/or the environment). 
UNICEF (Aflatoun \& UNICEF, 2012) stated that financial literacy capabilities that must be mastered by someone, in the end, include: a) Knowledgeable, educated, and informed about the issues of money and asset management, banking, investment, credit, insurance and taxes; b) Understand the basic concepts of money and asset management (eg investment value from time to time, and insurance risk); and c) Using financial knowledge and understanding to plan, implement and evaluate financial decisions.

In 2015, the OECD as an organization that pioneered a financial education program as well as an international student assessment program through its survey called the Program for International Student Assessment (PISA) presents a more detailed framework of analysis, definition and description of the domains assessed in PISA 2015, namely scientific literacy, literacy reading, mathematical literacy, and financial literacy. Financial literacy is define as the knowledge and understanding of financial concepts and risks, and the skills, motivations and beliefs to apply that knowledge and understanding in making effective decisions in all levels of the financial context, to improve the financial well-being of individuals and communities, and to enable participation in economic life. PISA defines financial literacy as pertains to youth, and it is organised around the content, processes and context that are relevant for the assessment of student (OECD, 2019).

At the age of pre-teens at the elementary school level of the upper class, children, in general, have interacted socially and gained various influences from peers. Moreover, the impact of media and technology that is powerfully positive and negative effects on the lives of children today (Anderson, 2007). On the positive side, adolescents can learn about social adaptation, tolerance, and diversity. But on the contrary hand, children nowadays have access that is too easy, and they become accustomed to instant things, including fulfilling their wishes and using their allowance.

Financial literacy for children and adolescents is needed because the majority of them are getting to know wasteful activities such as buying food, buying toys, buying funny and unique hobby items, going together with friends for activities that require funds, and so forth. The financial condition of parents positively influences this condition, financial education provided by parents, experience, and training received at school (Senjiati et al., 2018). Some children and adolescents believe that in interactions with friends, social status such as having clothes, accessories, and certain items, will be related to their self-acceptance in social situations (Cochran, 2010). A study revealed that many teens experience great feelings and pride when buying new goods (Courhanea et al., 2008). Therefore, children need to know about financial literacy to assist them in managing to spend and avoid consumerism as a provision for them in adulthood, where they can make credit cards quickly (Cochran, 2010) and financial management without control. Most children and adolescents turn to the adult world with little or no understanding of finance. This lack of knowledge causes expenditures beyond their real abilities (Butkowski, 2009). 
Referring to the "International Financial Education Framework for Children and Youth on Financial Education", which was launched by UNICEF (Aflatoun \& UNICEF, 2012) and the Guidelines for Organizing the Ministry of Education and Culture's Literacy Movement (2017), that put forward in the field of financial education in which children and young people for development assistance and research knowledge as follows:

- $\quad 1$ st level 1 (0-5 years old): Value of money, prices, savings, belongings

- $\quad$ 2nd level (6-9 years old): Needs and wants, savings plan, rewards, recognize banks and financial services

- 3rd level (10-14 years old): Informed consumer, short vs long term planning, financial risks, effects of advertising

- $\quad 4$ th level 3 (15+ years old): Negotiation skills, purchasing power, interest rates, financial crimes

The results of Aflatoun \& UNICEF's research (2012), showed that after obtaining a financial education program, children showed positive changes in:

- Saving behaviour - Children changed how and where they saved;

- Saving preferences - Strong increase in the percentage of children who keep at school and the amount of money saved;

- Risk preferences - Children became more aware and attuned to potential risks in financial transactions; and

- Locus of control - Children felt that they had more control over their actions and decisions.

Financial education provides opportunities for children and adolescents to have social and economic characteristics as citizens. Financial literacy competencies can help them become more "financially intelligent" and "resource smarter" in their lives (Drever et al., 2015). The role of financial education to strengthen creativity, productivity, competence, and the achievement of their own goals (Fernandes et al., 2014). In connection with the scarcity of children and adolescents who are familiar with financial education, it will be more challenging to overcome life's difficulties, be socially responsive, and become resilient citizens.

\section{Research Methodology}

The research methodology is a case study to answer three "how's" on the questions' research above (Yin, 2014). Case studies are used in design research to analyse a phenomenon, to generate hypotheses, and to validate a method (Teegavarapu et al., 2008). The type of case study in this research is single case with exploratory.

A population of this study is elementary school students in Bandung. Meanwhile, the sample of this research has taken by purposive random sampling and involved about 139 pupils fifth-grade students who involved in a survey conducted from January to March 2019 at four public elementary school and private elementary schools based on the consideration of the diversity of characteristics. 
The study should be empirically conducted based on the current conditions/ student profile, where the researcher assume that elementary school students in Bandung has lack on financial literacy since there are not formal programmes are served for them.

This study uses a questionnaire technique in the process of collecting data, where researchers ask students to fill their answer in a questionnaire to explore students' experiences and understanding of simple financial management. Student got about seventeen question where combining of multiple choice question (number 1 to 12) and essay question (number 13 to 17), as follows:

1. Mention the age when starting received the allowance

2. State the amount of compensation received

3. Mention the amount used from the contribution

4. Explain the allotment of usage of benefit

5. Mention other types of money received besides the allowance

6. Mention saving experience

7. Mention the nominal money saved

8. Name the place to save

9. Explain the plan to use the savings later

10. Mention the experience of contribution

11. Explain the purpose of the donation or assistance provided

12. Mention the nominal money to donate

13. Express opinions about proper money management

14. Mention a figure or role model that is considered useful in managing finances

15. Name family members who have taught about managing money and explain the process (if any)

16. Mention any activities in the school regarding money management (if any) and explain the process

17. Expressing expectations regarding financial management subjects in the future

\section{Results and Discussions}

The results of the survey succeeded in showing empirical data about daily experiences and students 'level of understanding of simple finances which were then the 18' questions were grouped into three aspects as follow: 1) students' involvement in interacting with money; 2) experience managing money; 3) knowledge of proper financial management. Each of these aspects shows empirical data obtained based on the survey results as follows: 


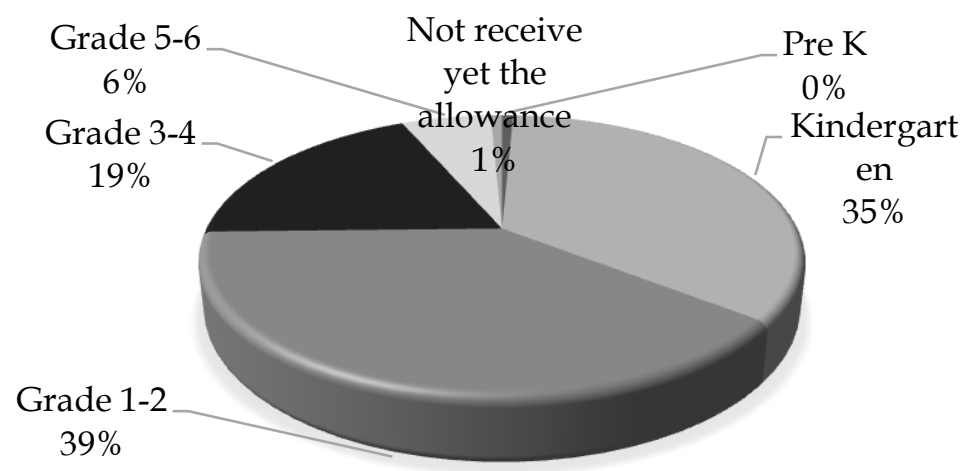

Diagram 1. The age when starting received the allowance

From the survey, some schools impose rules by allowing students to carry the allowance at certain class levels or with certain nominal limits. Diagram 1 shows that, on average, students have known about the allowance since kindergarten and elementary school in which their parents gave it at home (even though they did not bring it to school).

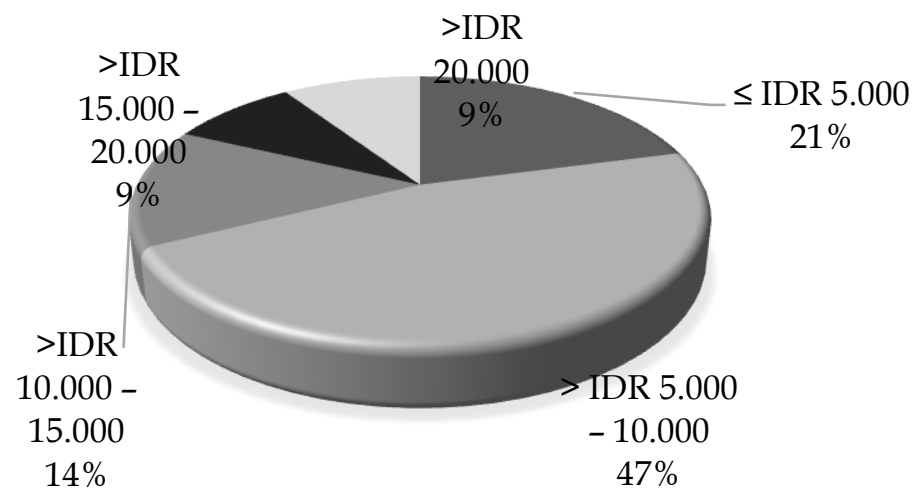

Diagram 2. The amount of allowance received

Diagram 2 shows the amount of allowance received by students every day, where most students receive an allowance is IDR 5,000 - 10,000 / day.

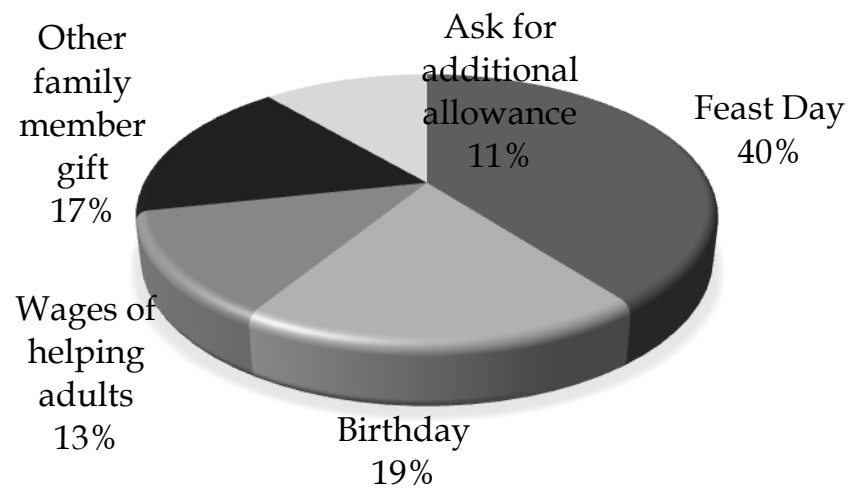

Diagram 3. The other types of money received besides the allowance

In diagram 3, we can see that in addition to the daily allowance, students also receive other money in special moments, such as birthdays and family gatherings, and sometimes in terms of small wages for doing something right. 
Students also have the opportunity to request an additional allowance from parents if the daily allowance is deemed lacking. Therefore, financial guidance and education are needed so that money is not only used for shopping purposes.

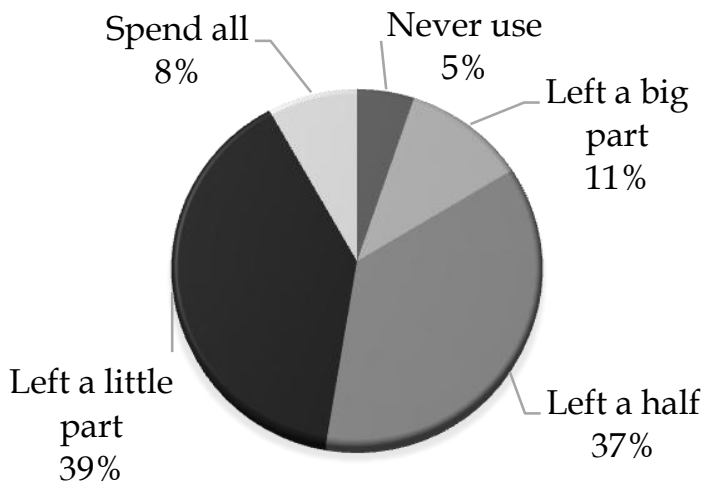

Diagram 4. The amount used from the allowance

Diagram 4 shows that most of the allowance given by parents and brought by students to school still leaves a small portion and half. This condition can be observed by schools to introduce students to the basic concepts of simple financial management such as saving and donating (sharing), and not only for shopping (spending).

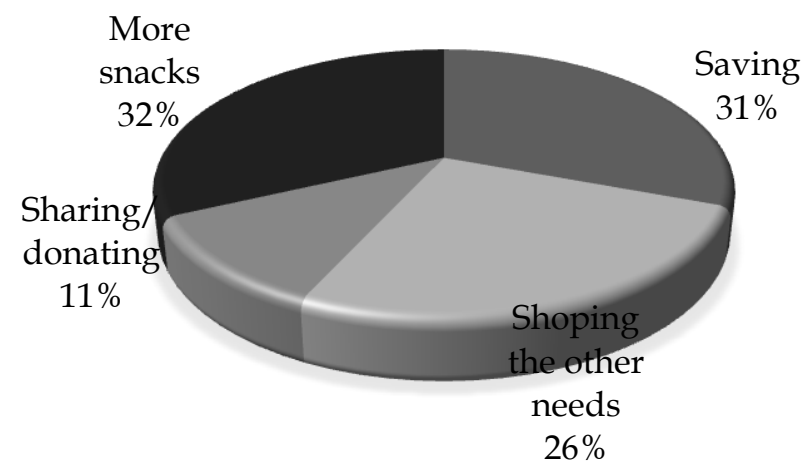

Diagram 5 the allotment of usage of allowance

Diagram 5 shows that most of the allowance for leftover snacks at school is used by students to return to shopping at home or outside of school and saving activities. The emergence of interest in saving money for students influenced by school policies and parenting parents at home.

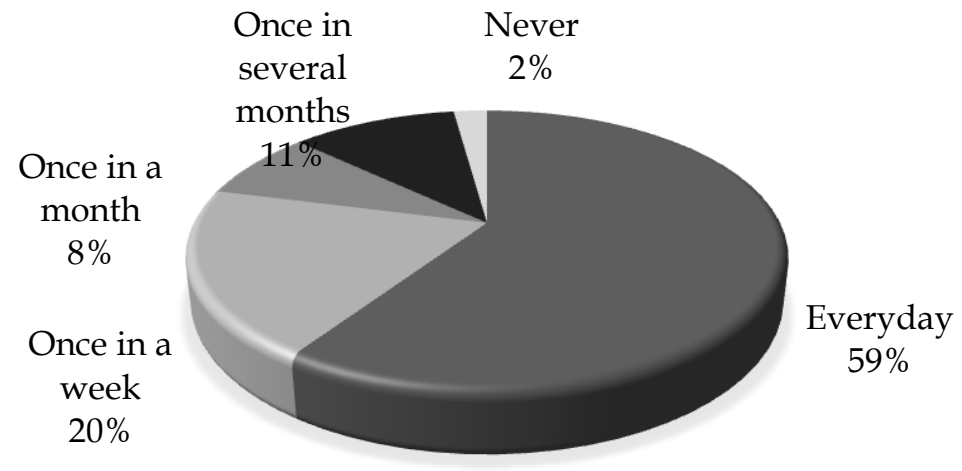

Diagram 6. The Frequency of Saving 
As shown in diagram 6, currently, most students are saving. But from the results of interviews with teachers, on average students collect with parents' direction, and the money parents have prepared separately from the allowance. There are a small number of schools that have student savings programs but are not required, and the amount and frequency of savings are not determined. However, most schools do not have a savings program, due to reasons: 1) there are regulations that teachers are not permitted to manage student or student parents' money, and 2) the school sees that saving patterns are carried out by parents and not student awareness. So that the impact, the ability and knowledge of students in managing the allowance they have for shopping activities (spending), donating (sharing), and saving is still fragile. In other words, according to what the class teacher said, saving activities were carried out by the students' parents and not the student's awareness. So it is necessary to create a financial education program for elementary school students to manage their allowances, where savings are obtained by setting aside benefits or daily allowances.

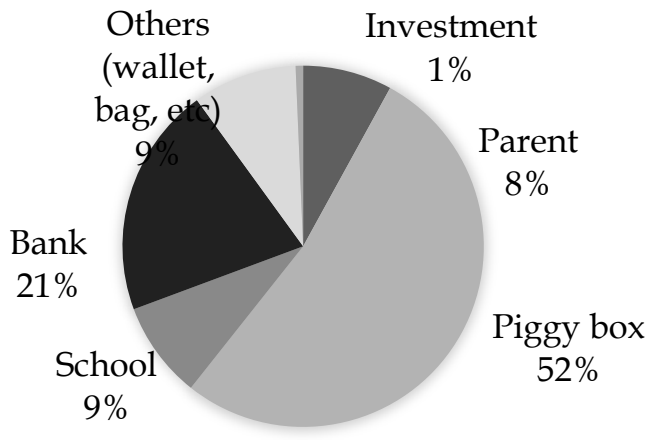

Diagram 7. The Place for Saving

Based on diagram 7 above, it shows the way students choose to save is quite diverse. This situation indeed occurs due to family habits and financial education patterns obtained by students from parents at home and teachers at school. Diagram 7 shows that a small proportion of students have utilized the services of cooperatives, banking, and there are still a few who invest in precious metals. However, most students even save in a piggy bank. It indeed becomes an opportunity for the school or the government to start providing knowledge about banking services that can be utilized by students in continuing their saving activities following the saving stage in the piggy bank is over because most students do not have long-term plans regarding savings. Most students still plan their savings to be used for shopping for daily needs, not much different from the program to handle their daily allowance. 


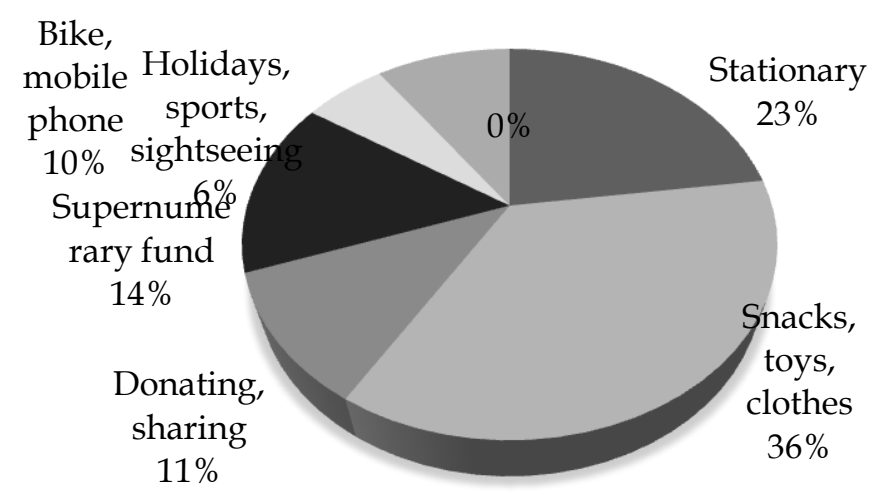

Diagram 8. Plans for Using Savings Money

Most students do not yet have the understanding that saving is one way to achieve more significant goals in the future. The students still aim to use savings for daily needs, as well as the use of daily allowances, as can be seen in diagram 8. However, some students already have the right concept of the purpose of saving, such as for reserve funds if there is an emergency, as one type of investment, for big plans in life in the future, to do hobbies, and to buy expensive things that are not currently owned and need time to have them.

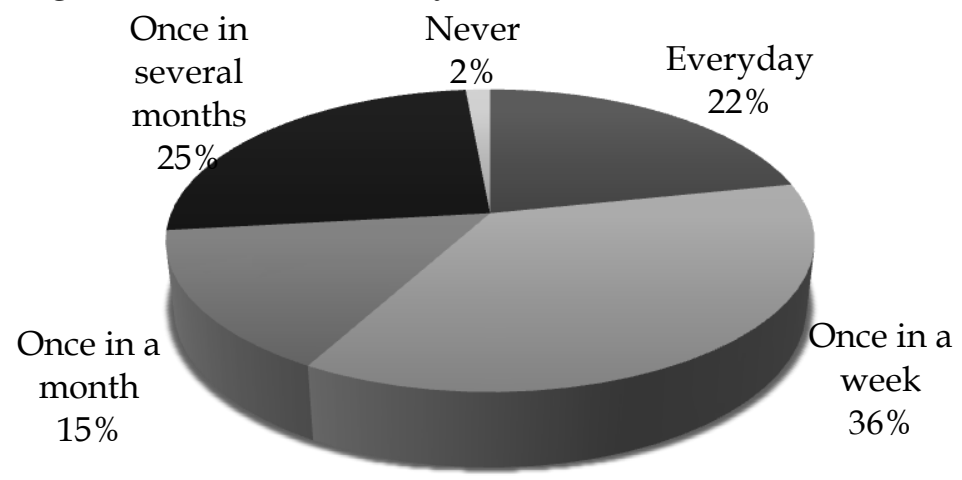

Diagram 9. Students Experience for Donating Money

Conceptually, all students already know the importance of donating and to whom donations can be distributed, even though the frequency of students making donations is still low. Diagram 9 exposes students already know whose their assistances are for friends, relatives, other people in need (e.g. beggars, older people, orphans, scavengers, victims of natural disasters, poor and disadvantaged people, and for the construction of places of worship. Some schools have distribution programs for student donation, although it is infrequent, for example only when natural disasters occur or on special religious activities. Some other schools do not have a distribution program for student donation. From the data above, researchers see the urgency of financial education not only to increase students 'ability to manage student' allowance for buying snack and saving, but also in improving students' understanding of the importance of setting aside allowances to be donated. That certainly fits the basic concept of financial education for elementary school students where students understand the function of money for spending, saving, and sharing (Maroto, 
2018). Besides, students need to be introduced to official institutions to channel donations to be more targeted and careful indirect donation institution.

In addition to revealing the experiences of elementary school students in conducting daily financial interactions, this research also tries to uncover the knowledge and concepts of financial management from the perspective of elementary school students. It determines the extent of students' financial literacy levels empirically. The understanding of financial management, according to surveyed students, is quite diverse. After summarized into sentences that can represent the diversity of choice of words used by elementary school students, the following is the definition stated by elementary school students regarding proper financial management is an ability to: 1) save money and not wasteful; 2) leaving the allowance so that all is not used up; 3) keep a portion of compensation; 4) turning cash into venture capital; 5) anticipate that someday the money runs out (bankrupt); 6) know the purpose of using money; 7) split money to be used, saved and donated; 8) consider buying only what is really needed; 9) sort shopping goods by looking for the cheapest prices; 10) save money safely and neatly; 11) selecting only shopping products that are really needed; 12) make a shopping plan; 13) count money accurately and quickly; and 14) delaying desires and prioritizing needs.

The concepts and definitions of proper financial management are obtained by students inspired by parents, family and friends who they pay attention to when interacting daily. There are some examples of managing the money, such as through family in managing salary and business as well as friends and relatives in managing allowance, which inspires students how to manage their finances in a right way.

Most students mentioned that they gained financial education experience at home. Adolescent family members like father, mother, brother, grandfather, grandmother are often provide direction regarding financial management. However, the elementary school students revealed that the pattern of financial education is still simple and merely advisory, not yet practical in ways to manage the allowance. For example, parents who advise to save the benefit and set aside allowance for savings, but they do not direct the amount and how concrete steps. Meanwhile, only a small number of students said they had never been taught about financial management at home.

Most students said that there was never a lesson or particular activity from the teacher regarding financial education to manage the allowance at school. Some students also stated that individual teachers and principals occasionally gave informal advice for the wise management of allowances such as frugality, not being wasteful, donating regularly and saving diligently. Finally, some students claimed that they had read books about economics and finance in the school library, and learned about money in mathematics and saving concepts in some of the school subjects. 
This situation mentioned by Capenhout (2015) that the role of parent involvement and teachers' role in financial education program is very important, but in fact is not well-developed.

\section{Conclusion}

The results of the study showed that in general, the Bandung City Elementary School students involved in the need assessment survey did not yet have financial literacy skills. They have not been able to carry out financial management independently and are still at the stage of making financial decisions according to instructions from their parents. Parents still play an essential role in managing student finances by always giving money in a post that has been transferred. For example, students are given two money posts, which is for spending and for saving. Indeed, this situation leads to the financial literacy ability of students is not well developed and relatively weak. The students are only competent in terms of spending money (shopping), while other concepts of $3 S$ (spending, saving, sharing) have not been done much by students.

The role of parents in financial education seems very significant, this is evident from the small number of students who have an adequate understanding of advanced financial management, such as saving, contributing, investing, doing business / looking for financial resources), which is an inspiration for students are the closest people around them (parents, family, relatives, or peers).

Compared to financial literacy stage proposed by PISA (2015), the Bandung City Elementary School students involved in this research survey are still at level 1, or even below. This condition is because most students have not been able to recognize the difference between their needs and desires in making simple financial decisions about daily expenses. Almost all students do not fully understand the value of money, such as they are not accustomed to comparing various products and prices when shopping. The students are not yet accustomed to planning and evaluating expenses that occur every day or every week on their allowance. If referring to the level issued by the OJK, the Bandung City Elementary School students involved in this survey are in the not literate and less literate stages.

\section{Recommendations}

This study' results lead researchers to offer some recommendations for stakeholders or further research to improve the financial literacy Elementary School students as follow:

- To develop a financial curriculum appropriate to elementary school student (integrated or separated with core curriculum at school).

- To designing the various financial program/ activities out of school in community centre.

- To socialize the important of financial education for children, especially for Elementary School students to parents, teachers, and stakeholders. 
- To design of proactive financial literacy programs, which take into account the role of parents and teachers in the financial socialization process.

\section{References}

Aflatoun \& UNICEF. (2012). Child Social and Financial Education. New York: Division of Communication UNICEF.

Allan, T. (2011). Financial Literacy Programs and Education for Young ChildrenImplikasi. USA: National Financial Education Council.

Anderson, S. G., Zhan, M., \& Scott, J. (2007). Improving the knowledge and attitudes of low-income families about banking and predatory financial practices. The Journal of Contemporary Social Services, 88(3), 443-452.

Arthur, C. (2011). Financial literacy in Ontario: Neoliberalism, Pierre Bourdieu and the citizen. Journal of Critical Education Policy Studies, 9(1), 188-222.

Australian Securities and Investment Commission (ASIC). (2012). MoneySmart teaching links to the Australian curriculum. Retrieved from http://teaching.moneysmart.gov.au/professional-learning/ teachingconsumer-and-financial-literacy/section-3/links-to-Australian-curriculum.

Blue, L. E. (2016). Financial Literacy Education with Aboriginal People: the Importance of Culture and Context. Financial Planning Research Journal, 91-105.

Blue, L.E. (2016). Exploring the financial literacy education practices in a Canadian Aboriginal community: A case study (PhD dissertation). Canada: Griffith University.

Blue, L.E., \& O'Brien, M. (2016). Primary students' compassionate approach to financial decision-making. Paper presented at Mathematics Research Group of Australasia (MERGA) the 39th University of South Australia on 5th of July. Adelaide, South Australia.

Blue, L.E., \& Brimble, M. A. (2014). Reframing the expectations of financial literacy education: bringing back reality. JASSA: The FINSIA Journal of Applied Finance, 1(2014), 37-41.

Cameron, M. P., Calderwood, R., Cox, A., \& Yamaoka, M. (2014). Factor Associated with Financial Literacy Among High School Student in New Zealand. International Review of Economic Education, 16(2014), 12-21.

Cochran, C. A. (2010). Financial Literacy in Teens (Thesis). Graduate Program Caldwell College: ProQuest \& UMI.

Cole, S., Sampson, T., \& Zia, B. (2009). Financial Literacy, Financial Decisions, and the Demand for Financial Services: Evidence from India and Indonesia. Harvard Business School: Working Paper.

Courhanea, M., Gaileya, A., \& Zomb, P. (2008). Consumer credit literacy: What price perception? Journal of Economics and Business, 60(2008), 125-138.

Credit Union National Association (CUNA). FiveTM: Teaching Your Preschooler About Spending and Saving. Retrieved from www.creditunion.coop/pre_k/index.html.

Drever, A. I., Odders-white, E., Kalish, C., \& Nelms, E. N. (2015). Foundations of Financial Well-Being: Insights into the Role of Executive Function, Financial Socialization, and Experience-Based Learning in Childhood and Youth. The Journal of Consumer Affairs, 49(1), 13-38.

Fernandes, D., Lynch Jr, J. G., \& Netemeyer, R. G. (2014). Financial Literacy, Financial Education, and Downstream Financial Behaviors. Management Science, 60(8), 1861-1883.

Habschick., M., Seidi, B., \& Evers, J. (2007). Survey of Financial Literacy Schemes in the EU27. Hamburg: Evers-Jung, Financial Services Research and Consulting. 
Hidajat, T. (2015). An Analysis of Financial Literacy and Household Saving among Fishermen in Indonesia. Mediterranean Journal of Social Sciences, 6(5), 216-222.

Holden, K. Kalish, C., Scheinholz, L., Dietrich, D., \& Novak, B. (2009). Financial Literacy Programs Targeted on Pre-School Children: Development and Evaluation. La Follette School Working Paper, No. 2009-009, 1-25.

Huston, S. J. (2010). Measuring financial literacy. The Journal of Consumer Affairs, 44(2), 296-316. http:/ / dx.doi.org/10.1111/j.1745-6606.2010.01170.

Jorgensen, B. L., \& Savla, J. (2010). Financial Literacy of Young Adults: The Importance of Parental Socialization. Family Relations, 59(October 2010), 465-478.

Kementrian Pendidikan dan Kebudayaan. (2017). Panduan Gerakan Literasi Nasional [Guide to the National Literacy Movement]. Jakarta: Kemendikbud. Jakarta: Kemendikbud.

Kementrian Pendidikan dan Kebudayaan. (2017). Materi Pendukung Literasi Finansial Gerakan Literasi Nasional [Supporting Material for Financial Literacy - National Literacy Movement] . Jakarta: Kemendikbud.

Lee, N. (2010). Financial literacy and financial literacy education: What might be the components of an effective financial literacy curriculum? University of London: Doctor of Philosophy Thesis.

Lusardi, A. (2015). Financial literacy skills for the 21st century: evidence from PISA. Journal of Consumer Affairs, 49(2015), 639-659. http://dx.doi.org/101111/joca.12099.

Mandell, L., \& Klein, L. S. (2009). The Impact of Financial Literacy Education on Subsequent Financial Behavior. Journal of Financial Counseling and Planning, 20(1), 15-24.

Maroto, M. (2018). Saving, Sharing, or Spending? The Wealth Consequences of Raising Children. Demography, 55, 2257.

McCormick, M. H. (2009). The Effectiveness of Youth Financial Education: A Review of the Literature. Journal of Financial Counseling and Planning, 20(1), 70-83.

Organisation for Economic and Cooperative Development (OECD). (2005). Improving financial literacy: analysis of issues and policies. Paris: OECD Publishing.

Organisation for Economic and Cooperative Development International Network on Financial Education (OECD INFE). (2012). OECD/INFE High-Level Principles on National Strategies for Financial Education. Paris: OECD Publishing.

Organisation for Economic and Cooperative Development (OECD). (2013). Financial Literacy Framework. In PISA 2012 Assessment and Analytical Framework: Mathematics, Reading, Science, Problem Solving and Financial Literacy. Paris: OECD Publishing.

Organisation for Economic and Cooperative Development (OECD). (2015). OECD/INFE Core competencies framework on financial literacy for youth. Paris: OECD Publishing.

Organisation for Economic and Cooperative Development (OECD). (2017). PISA 2015 Results (Volume IV): Students' Financial Literacy. Paris: OECD Publishing. http:/ /dx.doi.org/10.1787/9789264270282-en.

Organisation for Economic and Cooperative Development (OECD). (2019). PISA 2018 Financial Literacy Framework", in PISA 2018 Assessment and Analytical Framework. Paris: OECD Publishing. http://doi.org/10.1787/a1fad77c-en.

Otoritas Jasa Keuangan (OJK). (2016). Survey Nasional Literasi dan Inklusi Keuangan [National Literacy and Financial Inclusion Survey]. Jakarta: OJK.

Robson, J. (2012). The Case for Financial Literacy: Assessing the effects of financial literacy interventions for low income and vulnerable groups in Canada. Canada: Canadian Centre for Financial Literacy. 
Senjiati, I. H., Anshori, A. R., Maulida, I. S. R., \& Wahyudin, Y. (2018). Literasi Keuangan Syariah Bagi Anak School Age (Studi Kasus Pada Siswa Kelas 2 SD Darul Hikam Bandung)[Sharia Financial Literacy For School Age Children (Case Study of Grade 2 Students at Darul Hikam Elementary School in Bandung)]. Amwaluna, 2(2), 33-55.

Sherraden, M. S., Peters, C., Wagner, K., \& Clancy, M. (2012). Contributions of Qualitative Research to Understanding Saving for Children and Youth. Economics of Education Review, 32(2013), 66-77.

Teegavarapu, Sudhakar \& Summers, Joshua \& Mocko, \& Gregory. (2008). Case Study Method for Design Research: A Justification. Proceedings of the ASME Design Engineering Technical Conference, 4(10).

Triling B., \& Fadel. C. (2009). 21st Century Skills - Learning for Life in Our Times. San Fransisco: Jossey-Bass A Wiley Imprint.

Van Campenhout, G. (2015). Revaluing the Role of Parents as Socialization Agent in Youth Financial Literacy Program. The Journal of Consumer Affairs, 49(1), 186-122.

World Economic Forum (WEF). (2016). New Vision for Education: Fostering Social and Emotional Learning through Technology. Switzerland: WEF.

Xu, L., \& Zia, B. (2012). Financial Literacy around the World an Overview of the Evidence with Practical Suggestions for the Way Forward. The World Bank Development Research Group Finance and Private Sector Development Team.

Yin, R. K. (2017). Case Study Research and Applications: Design and Methods. California: SAGE. 